\title{
Niche Parties and Social Movements: Mechanisms of Programmatic Alignment and Party Success
}

\author{
Steffen Blings ${ }^{*}$ \\ Steffen Blings, Department of Political Science, Utah State University, Logan, Utah, USA \\ ${ }^{*}$ Corresponding author. Email: steffen.blings@usu.edu
}

(Received 4 July 2017; revised 30 January 2018; accepted 21 March 2018; firts published online

20 August 2018)

\begin{abstract}
Niche parties often originate in social movements, yet the latter's role in shaping these parties has received scant attention. I argue that movement roots can help niche parties achieve both vote- and policy-seeking goals by keeping core issues salient, bolstering issue ownership and securing allies in civil society. Employing interviews with movement, as well as Green and Pirate party leaders in Sweden and Germany, I identify three mechanisms (electoral pressure, grassroots linkage, elite orientation) that lead to programmatic alignment. This article extends an emerging research agenda that highlights how social movements shape party politics and offers evidence that niche party-movement interactions open new avenues for political representation counterbalancing mainstream parties' increasing detachment from civil society.
\end{abstract}

Keywords: social movements; political parties; representation; niche parties

Niche parties, political parties that focus on limited programmatic appeals regarding issues that are not easily located alongside the traditional, classdominated left/right dimension (Meguid 2005: 347-348), have received increasing attention. These parties have shaped contemporary European politics in important ways, as exemplified by the 2014 Scottish independence referendum backed by the Scottish National Party. Studies have illuminated the interactions between niche and mainstream parties (Meguid 2008; Pardos-Prado 2015), how voters respond to shifts in niche party positions (Adams et al. 2012) and when parties transition between mainstream and niche profiles (Meyer and Wagner 2013). No systematic attention, however, has been paid to the social movement roots that many niche parties have in common. Green parties originated from environmental movements, regionalist movements surrounded the origins of many ethnoterritorial parties, and more recently movements concerned with copyright, privacy and internet-related issues gave rise to Pirate parties. Parties' roots in and interactions with movements 
are important because they shape parties' behaviour and hold the potential to act as channels of representation from civil society to party politics.

I argue that niche parties with movement roots rely on programmatic connections with movements to keep their core issues salient, bolster their issue ownership and secure allies in civil society. Most of these parties, however, have organizationally decoupled from the movements which spawned them. How do niche parties under these circumstances retain their programmatic alignment with movements? Using 74 interviews with Green, as well as Pirate party leaders and elites in the environmental and digital movements in Sweden and Germany, I show that three mechanisms provide programmatic alignment. First, during electoral campaigns movements organize protests raising their core issues' salience and inform parties' core constituencies about the parties' performance, thereby assigning or threatening issue ownership. Second, a limited overlap of party and movement activists at the grassroots level continues to bring movement demands into party platforms. Finally, party elites engage in conscious efforts to position their party close to the movement that gave rise to it in two ways. First, especially when conflicts between movement and party threaten the latter's issue ownership, party elites seek movement organizations' advice regarding policy issues. Second, party elites independently adopt movement positions to prevent conflicts from arising in the first place. By aligning themselves with movements through these mechanisms, niche parties increase their chances of retaining their issue-oriented core constituencies and gain civil society allies regarding their policy demands. Accordingly, niche parties face more incentives to build closer programmatic connections to the movements that spawned them than mainstream parties face to build connections to societal interests with which they are aligned. Thus, movements continue to exert a strong influence on niche parties, despite lacking an organizational connection with them.

However, the mechanisms are not likely to apply equally to all niche parties and in particular unlikely to apply to right-wing populist parties. These parties are often organized in a top-down fashion, inter alia limiting the relevance of activist overlap at the grassroots level, and are surrounded by movements that operate in different ways from the movements surrounding, for example, Green or Pirate parties. Accordingly, I focus on niche parties on the (centre-)left and return to implications for other types of niche parties in the conclusion.

Demonstrating the significant consequences of interactions between social movements and political parties contributes to closing the existing gap between these areas of inquiry and highlights the value of linking institutionalized and noninstitutionalized forms of political participation (McAdam and Tarrow 2010). Existing work, mainly focused on state-movement relationships, has demonstrated significant effects of movement activity on institutionalized politics, including movements' roles as channels of representation (Johnston 2011). Movements are thus influential political actors, but their influence on parties remains understudied. This is puzzling considering the plethora of historical and contemporary connections between them. First, parties considered 'fringe' when they emerged have, in conjunction with social movements, shaped politics in important ways including the establishment of a new axis of competition in European party systems by Green and right-wing populist parties (Häusermann and Kriesi 2015). 
Second, in the context of growing electoral dealignment (Hernández and Kriesi 2016), niche parties have opportunities to become major players by winning over mainstream party supporters. In the aftermath of the debt crisis the relevance of parties with movement roots generally and niche parties particularly has increased even further, as evidenced by the rise of movement parties like Podemos in Southern Europe. Third, even with moderate parliamentary representation, niche parties have become important players in Europe due to the predominance of coalition governments. They often hold the balance of power and influence policies either as coalition partners or by lending support to minority governments (Bale and Bergman 2006; Little 2016). Because niche parties are central actors in contemporary politics, examining how they draw on movement connections to further their goals is important to understand policy outcomes and the makeup of party systems.

Moreover, exploring the interactions between movements and niche parties contributes to our understanding of the niche party type, movement strategies, and trends in political participation. Niche parties face different electoral incentives from those faced by mainstream parties and are punished for programmatic moderation (Adams et al. 2006). Illuminating the role movements play in holding these parties accountable helps identify the mechanisms producing that effect. It also contributes insights about movement strategies to pressure parties and about trade-offs between access (to one party) and influence (on other parties). Additionally, this study shows that the shift of activism from parties to civil society (Dalton 2008: 72) has implications for party politics, beyond the loss of party activists, and that citizens without party affiliation shape niche party platforms through movement activism.

This study highlights the important role movement organizations and niche parties play in ensuring political representation of (new) issues that are not represented by economically oriented mainstream parties. Together these actors open channels of representation at a time when mainstream parties, in their catchall and cartel party forms, have increasingly ceased to fulfil that function (Katz and Mair 1995; Kirchheimer 1966). Through the provision of programmatic linkages niche parties integrate into representative democracies voters who had lost or never developed confidence in those systems.

The next section presents a theory regarding niche parties-movement connections, before a third section discusses the data on four niche party-movement dyads. Afterwards, the mechanisms of programmatic alignment are introduced.

\section{Niche parties and social movements Party goals and movements}

Parties have to negotiate different aims ranging from vote- and office- to policyseeking goals (Müller and Strøm 1999). Niche parties, in particular, have to balance policy- and vote-seeking goals. On the one hand, these parties are less likely to follow changes in median voter ideology because they prioritize policy-seeking motives (Adams et al. 2006; Bischof and Wagner 2017). On the other hand, niche parties react to electoral setbacks by moving away from a niche profile in order to attract a broader electorate (Meyer and Wagner 2013). I argue that for niche parties 
seeking to negotiate these goals, social movements highlighting the same issues are attractive partners. Regarding policy gains, niche parties' initiatives will be strengthened if they can build on pressure exerted by civil society actors and coordinate with movement actors. If, for example, a niche party can take up policy demands of movement organizations in parliament, other parties know that they will be scrutinized on this issue by the niche party, as well as by civil society. Moreover, conflict-free relationships with the movements surrounding them allow niche parties to retain policy-motivated activists. Benjamin Farrer (2014) shows that niche activists' decisions on whether to exert influence by establishing a party or organizing within civil society are influenced by institutional factors. His argument also implies that when both party and movement organizations already exist, these actors compete for activists. Niche parties that move away from movement policy positions would be disadvantaged in terms of attracting these policy-motivated activists.

A close programmatic relationship with the movement also helps niche parties maximize votes. Scholarship has so far overlooked the role movements can play in influencing two of the factors Bonnie Meguid (2008: 24-27) identifies as the basis of (niche) party support: raising the salience of issues and assigning ownership over them. ${ }^{1}$ Niche parties profit from a high salience of their core issue since a higher number of voters will take the issue into account when casting a vote (Meguid 2008). This strategy will be particularly successful if the party is seen as the legitimate owner of its core issue - that is, the party best placed to handle the issue (Petrocik 1996). Social movement organizations (SMOs) have an independent interest in the salience of their issue and accordingly are helpful in keeping the parties' electoral niche open. Furthermore, an endorsement from these organizations will be helpful for niche parties, since these parties' issue-focused core electorates are likely tuned in to the messages of non-governmental organizations (NGOs). These endorsements from civil society help niche parties to solidify their status as 'associative owners' - that is, the party that citizens automatically connect to the issue (Walgrave et al. 2012). More importantly, (implicit) support from movement organizations also allows a niche party to be seen as the most competent party in handling its core issue, what Stefaan Walgrave et al. (2012) describe as issue ownership's 'competence dimension'. Many niche parties have an advantage in retaining associative ownership because they brought their core issues into the electoral arena. Challenges to their ownership on the competence dimension, however, represent a significant threat to parties' electoral fortunes, because they often rely on core electorates that look for clear policy programmes - that is, a party providing strong programmatic linkages (Kitschelt 2000; Lawson 1980). Thus, voters who prioritize these linkages are likely to abandon niche parties if the parties' competence is challenged, for example through policy conflicts with credible civil society actors like SMOs. Since many niche parties are small, any loss of support from the core electorate is problematic, because it might immediately threaten parties' parliamentary survival.

Thus, niche parties have an interest in programmatic alignment with social movements. Yet, because it is not in the interest of movements to tie their fate to one small party, movements have often organizationally decoupled from the niche parties they spawned. ${ }^{2}$ Strong connections to any political party inhibit 
SMOs' capacity to mobilize support from citizens with different party-political attachments and restrict their ability to lobby governments of all party-political compositions. Moreover, many movements in the second half of the 20th century took a generally sceptical attitude towards political parties (Kriesi et al. 1995). How do niche parties under these circumstances optimize their chances of policy and electoral success? I argue that they rely on three mechanisms that create programmatic alignment between party and movement, which are developed below.

\section{Mechanisms of programmatic alignment}

Existing scholarship has suggested that elections represent an important intersection of conventional and contentious political participation (McAdam and Tarrow 2010). During electoral campaigns we should expect movements to exert pressure on established political actors through a mechanism Doug McAdam and Sidney Tarrow (2010) term 'proactive electoral mobilization', which 'occurs when movement groups become active in the context of an electoral campaign' (McAdam and Tarrow 2010: 533). ${ }^{3}$ For movements, electoral campaigns are prime opportunities to elicit politicians' public commitments to policy goals and get movement messages heard by a public that is more attentive than usual. Accordingly, they work to raise their issue - through protests, for example - and to pressure parties into committing to their policy proposals, for example in mediahosted debates. For niche parties, however, elections are often more threat than opportunity as many of them have to fear the loss of parliamentary representation. Their chances strongly depend on the saliency of their issue during the election. Thus, with respect to putting the niche issue on the agenda, parties' and movements' incentives are aligned. Niche parties additionally have a strong interest in movement endorsements because their core electorate is likely tuned in to SMOs' messages. Thus for niche parties, programmatic alignment with a movement with which they share an issue focus is likely to be electorally rewarding.

Hypothesis 1: During electoral campaigns SMOs focus on placing their issue on the agenda and informing voters about parties' performance on this issue. Niche parties are particularly receptive to this pressure (electoral pressure mechanism).

Party-movement connections outside of the campaign season have received even less attention than links between movements and elections. I argue that grassroots activists link niche parties to the movements from which they originated. Policymotivated activists can work for their programmatic demands in the electoral arena, by joining a party, or within civil society - for example, through movement activism (Farrer 2014). Some activists choose to divide their time between those two arenas and are niche party members, as well as movement activists. Thus niche parties and movements remain connected through an overlap of activists on the grassroots level. Many of the niche parties on the (centre-)left on which this article focuses value participatory structures allowing members to shape policy platforms (see e.g. Burchell 2002 on Green, and Bolleyer et al. 2015 on Pirate parties). These structures allow party members with movement backgrounds to place movement 


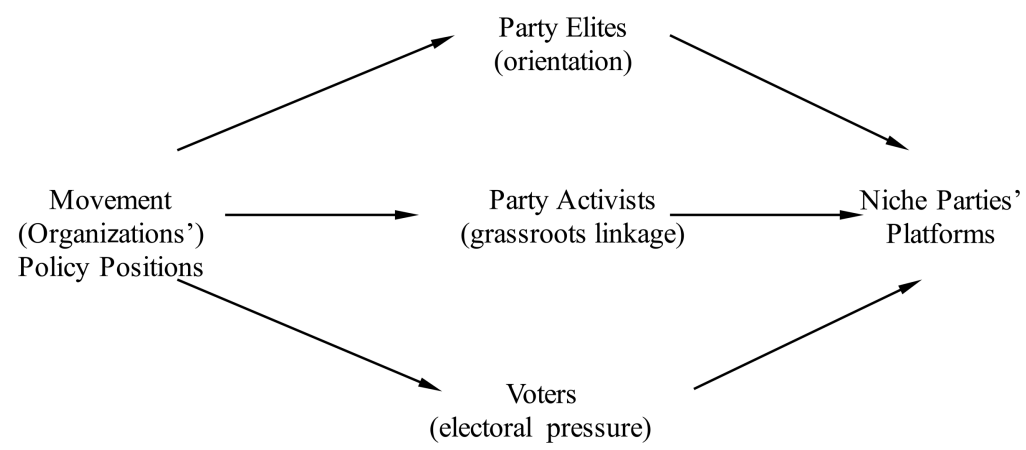

Figure 1. Mechanisms of Programmatic Alignment

demands in their party's platform through a mechanism I term 'grassroots linkage' and organically keep niche parties close to movement demands.

Hypothesis 2: Party members with movement backgrounds carry programmatic demands from movements into niche parties through those parties' participatory structures (grassroots linkage mechanism).

Finally, I argue that niche party leaders are aware of the need to align their parties with movements in order to retain their core electorates. Thus, they consciously seek to position their parties close to movements to ensure positive evaluations and elicit some cooperation in agenda-setting efforts and policy initiatives. This goal can be accomplished in two ways which together constitute a mechanism I term 'orientation'. First, I expect party leaders to solicit advice directly by contacting movement organizations. Second, party elites will seek out publicly available information about movement demands and adopt these demands on their own initiative.

This mechanism decreases the potential for policy conflict between party and movement and therefore for threats to the party's issue ownership. Direct contact, moreover, reassures SMOs that their positions are important to the niche parties and provides the opportunity to coordinate programmatic initiatives, increasing the likelihood of policy success for both actors.

Hypothesis 3: Niche party elites seek to position their party programmatically close to movements by seeking the latter's advice and adopting their positions independently (orientation mechanism).

Figure 1 summarizes the mechanisms creating programmatic alignment and highlights that different actors drive them. These mechanisms additionally permit SMOs to operate in a genuinely non-partisan fashion. During electoral campaigns, movement organizations focus on voters rather than interacting with parties directly. Grassroots linkage occurs on the activist, not elite level and the advice of organizations is available to all parties interested in it. Finally, party elites' efforts to align their parties with movements do not require any action by movement organizations besides making their positions public. Accordingly, SMOs influence niche parties without strong formal or informal ties to them and thus retain their 
capacity to lobby governments of all partisan compositions and the ability to mobilize support from citizens across the political spectrum. While this limits niche parties' room for manoeuvre with respect to their programmatic platform, they profit by gaining an ally that promotes the same policy agenda in civil society and provides indirect electoral benefits by raising the salience of parties' core issues and bolstering their issue ownership.

\section{Non-niche parties and programmatic alignment}

While these mechanisms are ideally suited to tie niche parties and movements together programmatically, they are less likely to connect non-niche parties with the societal interests around them. Niche parties rely on programmatically motivated voters (Adams et al. 2012: 1275-1276) and adjust their policy positions in line with policy moods among that core constituency rather than mean voter shifts (Ezrow et al. 2011). This constituency focus fits with parties being 'generally conservative, risk-averse organizations protective of their reputation among voters' (Meyer and Wagner 2013: 1248) since for niche parties, which are often small, losing core voters could easily spell the loss of parliamentary representation. Many non-niche parties also have roots in civil society (Lipset and Rokkan 1967) but moved away from these roots towards electoral-professional party models (Panebianco 1988) - that is, parties relying on a professional staff with a primary focus on electoral success, including catch-all (Kirchheimer 1966) and cartel party models (Katz and Mair 1995). This does not mean that these parties have stopped connecting to voters through linkages that are responsive to programmatic demands (Kitschelt 2000; Lawson 1980). However, it does imply that they cannot afford to concentrate on one issue or adopt the precise demands of a movement for fear of alienating voters since they aim at winning support from the broadest possible set of sectors in society (what Kirchheimer (1966: 192-195) for the case of catch-all parties described as 'limited integration' between the party, interests groups and voters). ${ }^{4}$ Parties have developed new forms of interest aggregation, for instance 'sanitized aggregation' in which parties incentivize voters to focus on issues that are 'non-controversial' and 'not electorally dangerous' (Lawson 2004: 261). Thus reacting to pressure from narrow (movement) constituencies is less attractive for non-niche parties and their programmatic platforms will be less close to their civil society environments than niche parties' platforms.

Beyond the larger incentives to follow core constituency preferences, some elements of the mechanisms tying niche parties to movements are less likely to work for non-niche parties due to the civil society interests closest to them. Protest to raise the salience of an issue as part of 'electoral pressure', for instance, comes more naturally to movements than interest groups, and niche parties remain more often surrounded by mobilized movements than mainstream parties (for example, in the case of Green parties and environmental movements (Kitschelt 2006)). Interest groups, moreover, are less likely than movements to build a base of activists that can carry their policy ideas into parties through 'grassroots linkage'. Finally, differences in party organization make the mechanisms better suited to niche than non-niche parties. The literature on party organization has often argued that party activists tend to be policy-seeking, while leadership leans towards 
office-seeking motivations. Paul Marx and Gijs Schumacher (2013), for example, demonstrate that whether social-democratic parties turned to neoliberal policies depended on whether party leaders were dominant vis-à-vis activists. Daniel Bischof and Markus Wagner (2017) apply this reasoning to niche parties hypothesizing that the parties' failure to follow median voter positions is due to activists' influence. They only find 'very weak evidence' for that hypothesis (Bischof and Wagner 2017: 6) and thus that activists are not the driving force anchoring niche parties on the left/right dimension. However, the more participatory structures of niche parties are still likely to allow activists to carry movement demands (often on a dimension other than left/right) into their parties. In sum, stronger incentives to focus on core (movement) electorates, the lack of movement mobilization around non-niche parties, and their less participatory structure make it less likely that the mechanisms apply to non-niche parties.

The next section introduces the data regarding four party-movement dyads used to explore these mechanisms.

\section{Green and Pirate parties and movements in Germany and Sweden}

As discussed above, Meguid (2005) defines niche parties as those focusing on limited, non-class issue appeals that cannot easily be located along the dominant dimension of electoral competition. This article focuses on four parties matching this definition. ${ }^{5}$ First, it considers the Swedish and German Greens. Most Green parties originated in environmental movements and found core support among citizens sympathizing with these movements (Kitschelt 1988). The Swedish and German Greens are no exception and environmental issues remain central for them (Bale and Bergman 2006; Blühdorn 2009). They are surrounded by a sizeable environmental movement organization sector (Boström 2008; Rucht and Roose 2004). Second, I examine the Pirate parties in the same countries, which are much younger (both founded in 2006) and brought to the fore privacy, copyright law and generally issues resulting from the increasingly central role information plays in contemporary societies (Demker 2014). In both countries, these parties originated in the presence of a digital movement that focused on the same issues these parties highlight (Dobusch and Gollatz 2012; Lindgren 2013). ${ }^{6}$

Focusing on these four parties has several advantages. First, all parties are cases of the centre-left niche parties with strong participatory structures on which this article is focused. ${ }^{7}$ At their origins, Green parties provided open internal structures allowing activists strong influence on the parties' platforms (Kitschelt 1989) and while not all of these elements have survived over time, Green parties retain strong participatory elements (Burchell 2002). Pirate parties have similarly committed to allowing activists extraordinary sway over their platforms (Bolleyer et al. 2015). Second, all four parties coexist with movements that stress their core issues, allowing the analysis of party-movement interactions. While many niche parties operate in movement environments, that is not true for all of them. Accordingly, the findings of this article are limited to niche parties surrounded by (mobilized) movements - that is, movements that have an activist base that can be mobilized for (contentious) action and 'underlying social networks' (Tarrow 1998: 3) to accomplish that mobilization. Third, selecting a niche party family struggling to 
keep its niche open (Pirate parties) and one that is well-established (Green parties) includes variation with respect to the stability of the parties' roles in their party systems. This facilitates exploring whether temporal distance to the parties' movement roots matters. Fourth, including parties that focus on two different issue niches (the environment and information-related issues) guards against inferences about niche party-movement connections that are unique to one issue. Finally, choosing one of the most studied niche parties (the German Greens) and the original impetus for Pirate parties across the world (the Swedish Pirates) allows me to make use of secondary sources about the parties' histories and focus on empirically important cases.

To explore the role movements play in niche party success, I employ data from 74 semi-structured interviews conducted with leaders in the four parties as well as elites in the environmental and digital movements in Germany and Sweden in 2013 and 2014. The interviews were guided by a semi-structured questionnaire focused on the interactions of parties and movements in general and on three potential arenas of interaction - electoral campaigns, platform formulation processes and elite recruitment - in particular. ${ }^{8}$ Focusing on electoral campaigns allowed me to explore behaviour when parties are most focused on their vote-seeking goals and whether movements engage in 'electoral pressure' (Hypothesis 1), as well as whether parties are receptive to that pressure. Platform formulation processes provide insight into how policy-seeking goals are pursued and whether activists play the role hypothesized by the 'grassroots linkage' mechanism (Hypothesis 2). Finally, a focus on elite recruitment examines whether links that would ease 'elite orientation' (Hypothesis 3) exist.

Interviewees in political parties were selected on the three potential arenas of interaction (that is, those likely to be involved in planning national campaigns, formulating platforms, and/or having oscillated between movement and party). On the movement side I identified relevant organizations using primary and secondary sources and requested an interview with the person in the organization most familiar with interactions with parties. ${ }^{9}$ I moreover drew on snowball sampling, asking interviewees for further contacts to ensure that I was aware of all relevant actors. ${ }^{10}$ These data are ideal to investigate how parties and movements interact, since they allow an analysis of dyadic pairs of actors (niche party elites/movement elites in the movement that gave rise to that party). The interviews provided an overview of these interactions and each actor's role in them from a number of perspectives and made it possible to identify beliefs on which behaviour is based and how that behaviour is perceived by the other relevant actors. ${ }^{11}$

\section{Mechanisms of programmatic alignment}

This section explores the three mechanisms of programmatic alignment discussed in the theory section.

\section{Electoral pressure}

Movement organizations have developed a repertoire of campaign activities to raise their issues and inform voters without running the risk of being perceived as partisan. Specifically, SMOs publish reports summarizing their evaluations of 
parties' commitments to the movements' core issues and organize protests shortly before national elections. Thus, these movements are engaged in 'proactive electoral mobilization' (McAdam and Tarrow 2010: 533) in which SMOs target voters by providing information. This puts pressure on parties to position themselves in such a way that they do not become the target of a negative report or protest. This pressure is especially strong for niche parties because a negative evaluation by those considered to be the experts on their issue within civil society could be disastrous for a party centring its appeal on one issue.

About a quarter of interviewed SMO representatives indicated that reports are part of their organizations' campaign activities. ${ }^{12}$ The reports are often based on answers that parties or individual candidates provide on surveys sent out by the organizations. These publications allow SMOs to inform voters about which party is most in line with movement demands without issuing an explicit endorsement, leading one movement leader to describe the surveys his organization sends out before elections as 'a very elegant option to participate in the political discourse without having to position ourselves' (interview 010201). Since these reports are published by organizations they are less common in less institutionalized movement environments such as digital activism in Sweden.

The importance of these reports is recognized by niche parties. About $31 \%$ of interviewed party leaders independently referenced them when discussing their interactions with movements during electoral campaigns. A former leader of the Swedish Greens stressed the reports' advantages:

So they never came out really [and] say: 'Go and vote for the Greens', but ... before almost every election ... they have checked the behaviour of the parliamentary parties and also checked their programmes. And then they make lists and most often the Greens come on top of these lists from their point of view. And I mean then they don't have to add: 'Go and vote for the Greens'. I mean the message is pretty clear ... So that's the way it works now and has worked for a couple of decades. (interview 020308)

The Swedish Greens did in fact receive the best evaluations in the Swedish Society for Nature Conservation's (SNF) reports regarding the European, as well as national election in 2014 (Junker 2014; Naturskyddsföreningen 2014).

The parties, however, know that they need to position themselves close to movement demands to retain these results in SMOs' reports and the related electoral benefits in solidifying and growing a core electorate. One Swedish Green member of parliament (MP) summarized the situation during election campaigns: 'So now for example they are sending us surveys ... asking us what will the Green Party do in these different topics and what we answer is publicly presented. So they put quite a lot of pressure on us in performing what we are promising ... and more or less form ... what we would focus on' (interview 020303).

Occasionally, niche parties find themselves singled out for movement pressure. One leader of the anti-nuclear movement in Germany described how the Greens' efforts to highlight their issue ownership made them vulnerable to movement pressure. Because the Greens 'very much ... publicly cultivate this image that they are the only anti-nuclear party' (interview 010412), the organization was able to devise a strategy for the 2013 election focused on pressuring the Greens to adopt a 
faster phase-out of nuclear energy as one of their key demands for a potential government coalition. The organization commissioned a poll showing that Green Party voters overwhelmingly favoured a faster phase-out and published it in an advertisement in a national newspaper (interview 010412) that originated in the same movement contexts that gave rise to the Greens and accordingly is read by many of the party's core voters.

Niche parties also profit from protests SMOs organize during election campaigns to raise the salience of the movement's core issue. For the movements represented in this study, protests were most prominently used by the digital movement, which has organized a yearly protest against surveillance in Berlin under the title 'Freedom not Fear' since 2006. In the election years of 2009 and 2013, the protest took place about two weeks before the elections. Similarly, the Pirate Bay Trial, as well as the Swedish Parliament's (affirmative) vote on the European directive to enforce intellectual property, led to a period of movement mobilization and activists gathering in Stockholm in early 2009 (interview 020203). This mobilization occurred right before the European elections of the same year and contributed to opening space for a party focused on the movement's issues. In that election the Swedish Pirates achieved their breakthrough.

An additional tool that movements employ to raise the salience of their core issues and pressure parties at the same time is the discussion event, which forces parties to defend their policy positions. These events take a number of forms including panels and debates and some are organized by the SMOs themselves (interview 020401), while others are hosted by the media (interview 010406).

In sum, during electoral campaigns, movement organizations use a variety of means to keep their issues salient and inform voters about party performance on the movements' issues. The SMOs take great care to remain non-partisan by engaging with all parties in the same way (for example, by evaluating all parties based on the same survey). Niche parties stand to profit electorally from implicit endorsements and their core issues' increased salience, as long as they align their policies with movement demands.

\section{Grassroots linkage}

About 38\% of interviewed party leaders observed that their parties integrate movement demands into their platforms because of party members who are also movement activists. These members bring policy goals from movements into the process through which niche parties formulate their platforms. Most party elites see this mechanism as working predominantly at the grassroots of the parties. ${ }^{13}$ When asked about the influence of external groups on the party platform, a former member of the German Pirates' national leadership highlighted that there was no 'influence of groups as such', but that 'where personal overlaps exist texts are certainly being adopted', continuing: 'Our electoral law proposal originates with Mehr Demokratie e.V. [a SMO pushing for more direct democratic elements in electoral law]. But I have already said that there are also Pirates who are members of Mehr Demokratie e.V. and that [the Pirates adopting the proposal] is actually because Pirates like the proposal of an NGO and introduce it' (interview 010102). 
The youth organizations of niche parties, in which personal contacts to and overlapping memberships with movements are more common, seem to play a particularly relevant role in bringing movement ideas to parties. Politicians in the German and Swedish Greens (interviews 010302, 010304, 010306, 020305, 020307), as well as Swedish Pirates (020101, 020105) highlighted the role of their parties' youth organizations in shaping platforms, with one German observer stressing that: 'The Green Youth is strongly represented in those movements. And for them the Green Youth is in effect one of those points of connection between a party that one is giving impulses and the network from which they [the movements] originate' (interview 010302). Thus movement activists who are also members of parties' youth organizations use that membership to introduce movement demands into parties' platform formulation processes.

Movement organizations, however, practise a non-partisan approach and do not coordinate or actively encourage influencing parties through an overlap of activists at the grassroots level. In fact, only a single interviewed movement leader referenced influencing party platforms in this way.

The overlapping grassroots again highlight the importance of core constituencies for niche parties, since not only their voter, but also the movement activist base are recruited from these constituencies. This linkage, however, seems to play a larger role in younger parties, as it was mainly discussed by Pirate Party elites. ${ }^{14}$ Thus, in these parties grassroots activists ensured that the party would not drift from movement policies and risk its relationship with an important ally in defending the salience of the parties' electoral space.

\section{Party elite orientation}

The most common mechanism of programmatic alignment that party elites highlighted was their two-pronged effort to ensure that the party platform matched movement demands. Party leaders: (a) seek the advice of SMOs on a case-by-case basis and (b) draw on publicly available information about movement positions without active input from the movements themselves. The result is some "cautious coordination' to keep the core issue of party and movement salient and further policy campaigns, as well as the avoidance of conflict between the two actors, preventing threats to the parties' issue ownership.

\section{Direct influence through advice}

Almost two-thirds of party elites referenced eliciting advice from civil society, and representatives of SMOs mentioned providing such advice with a similar frequency. ${ }^{15}$ This direct contact is usually initiated by party elites and mainly takes place on three occasions. First, MPs reach out to organizations for input during the legislative process. Second, niche parties consciously offer SMOs opportunities for influence during the parties' platform formulation processes. Third, informal exchanges play a role in agenda-setting.

MPs occasionally contact movement-affiliated NGOs for advice and expertise, as well as to make sure that they do not move too far from movement demands (about 78\% of interviewees who are or were once MPs made reference to this kind of contact). In these exchanges, politicians draw on the knowledge of (scientific) 
experts in the NGOs to help them formulate positions regarding issues currently before parliament and to develop their own proposals or questions for the government. Usually these kinds of consultations occur through non-public, direct contact between staff at SMOs and MPs, but occasionally consultations are conducted in public ways. At Almedalsveckan 2014, a yearly Swedish political event on the island of Gotland, for instance, the Swedish Society for Nature Conservation hosted a panel on water power at which representatives of environmental organizations, including the Swedish Society for Nature Conservation itself and the Världsnaturfonden WWF, answered questions from politicians from several parties, including the Greens' environmental spokesperson in the Swedish parliament.

Niche parties use these interactions to remain close to the movements. One Green member of parliament in Sweden summarized his motivations for getting in touch with movement organizations as follows: 'I want to check the course, the direction of my work. Am I right?' (interview 020305). A representative of the SMO identified as central to his work by this MP confirmed that the organization occasionally provides advice to politicians, for example, with respect to framing and fact-checking. The representative, however, also stated that personal interest rather than party-affiliation determines whether politicians seek out the organization's advice (interview 020403). This answer is typical of the non-partisan attitude with which NGO representatives describe their organizations' approach to direct interactions with politicians. These organizations are usually happy to provide advice and advance their agenda through these interactions, but they consistently stress that their expertise is equally available to all parties. However, niche parties have stronger incentives than mainstream parties to seek the expertise of the movements that gave rise to them because their issue focuses align. Additionally, cultural affinity between movement and niche parties further eases these interactions. A representative of a German environmental organization, for example, observed that the Greens are the party most attentive to their demands, because they need the organization's expertise and listen less to business associations than other parties (interview 010407). Thus niche parties use these contacts to signal their attentiveness to movement demands.

Niche parties are especially likely to seek input from SMOs when they have to make decisions that could cause conflict with the movement and thus threaten voters' perceptions of the party as legitimate owner of the issue. When the German Greens, for example, had to decide whether to support a government proposal for nuclear phase-out that some in the movement did not consider far-reaching enough, the party's leadership sought close contacts with movement organization elites (interviews 010406, 010411, 010412, 010413) and held meetings with several organizations to discuss the party's position (interviews 010406, 010412).

The organizations interpreted this behaviour as driven by the party's strategic concern with avoiding conflict: 'the party leadership and those who were afraid that the Greens would be torn apart internally had an interest in receiving support for their position from important environmental associations ... It was about the question, do they vote in favour or not in the end and will they receive criticism from the environmental associations or not' (interview 010406). 
The Greens eventually settled on supporting the government's proposal and avoided a clash with the anti-nuclear and environmental movements by using the different positions in the movements strategically to highlight SMO positions in line with the party's view. In that way the party avoided criticism from the movement and averted a threat to its ownership of the anti-nuclear issue.

Niche parties also seek the input of civil society - in particular from organizations affiliated with the movement that gave rise to the party - when formulating the party platform. The Swedish Green and Pirate parties, for instance, have both adopted platform formulation processes in which the public can contribute ideas online (interviews 020101, 020304). For all parties, movement demands also found their way into discussions of platforms through existing contacts with movement activists. The two Green parties, which operate in more institutionalized movement environments, even host meetings with NGOs or send drafts to civil society groups during their platform formulation processes (interviews 010305, 010306, 020304). These parties have also created political foundations or think-tanks through which they organize contact with the movements (described by about $35 \%$ of Green elites). Thus, these foundations provide brokerage. ${ }^{16}$

Green parties also engage in occasional, informal contacts with SMOs to keep environmental issues visible, as a Swedish MP recalled: 'We cooperate sometimes in harmonizing our campaigns. Not formally, but we meet up every once in a while and discuss: which topics are you going to focus on and so on' (interview 020303). A staff member of the German Greens described a similar exchange of information on an informal level about the issues that the party and movement organizations expect to become important and the plans these actors have regarding those issues (interview 010306). This 'cautious coordination' allows parties to win an ally in civil society that independently works towards shared policy goals.

\section{Indirect influence and orientation}

Party elites also consciously and independently adopt movement positions. Almost half of the interviewed party elites made reference to having independently sought out information about movement demands and followed those positions in their work.

SMOs setting the agenda and niche parties picking up those issues help increase the issue's salience and the likelihood of policy success by building pressure in the civic as well as parliamentary arenas. A former party leader of the Swedish Greens recalled:

If they [the SNF] or Greenpeace or someone would have a initiative and trying to raise a certain issue, it would be quite probable that one or two of the Green parliamentarians would take that up and do something about it politically, like put [a] question to [the] minister ... Not as an official cooperation, but because when they have their campaigns it affects us ... and we realize that this issue is actually something that we should do something about. (interview 020307)

Niche party elites also align themselves with SMO positions without direct interaction with the movement. One Green Swedish MP described this process: 
To give you one example, we, both the Green Party and Greenpeace, were discussing we need to set a goal for energy policy in Sweden ... And they [Greenpeace] set a date to 2030 and it was not a coincidence that we also decided on 2030 as the same goal ... out of the idea that we want to have the same goal as them, we set the same date. (interview 020303)

This kind of independent orientation ranges from adopting specific policy goals to parties including movement demands in their platforms. A former member of the German Pirates' federal leadership recalled how the party's platform was shaped by movement NGOs: 'demands that Mehr Demokratie e.V. made were for instance adopted into the Baden-Württemberg state election platform. Or the Pirate Party has looked at the list of demands of Transparency International and has adopted it as requirements for its own work' (interview 010114).

Movement organizations are aware that they exert pressure simply by making their positions publicly known, leaving the party the option of adopting the position or being publicly in conflict with the movement. A representative of the German Nature and Biodiversity Conservation Union (NABU) summarized this as follows: 'we don't say, we advise the Greens to do this or that, but we say the NABU demands this or that ... And by making our position public, journalists will look at whether that is congruent with what the Greens say or whether there is a discrepancy' (interview 010406). Thus the SMOs' work is non-partisan, but since the niche parties remain focused on their original core issues, the influence of these publicly available policy positions is largest on the niche parties.

In sum, by drawing on information from SMOs, either directly acquired through advice or indirectly obtained through public sources, niche parties position themselves close to movement demands, retain issue ownership, raise their issues' salience and increase their likelihood of policy success.

\section{Summary}

Figure 2 illuminates the relative frequency with which relevant interviewees highlighted the three mechanisms of programmatic alignment explored in this section, separated by party and movement actors. Since the grassroots linkage and independent elite orientation are almost exclusively observable to party actors, only percentages for party actors are provided for those mechanisms. Moreover, because they represent the central basis for informing voters during electoral campaigns, reports about the performance of parties published at election time stand in as a proxy for electoral pressure here. Percentages of interviews are given to provide a sense of how many interviewees highlighted the mechanism and are not observations representative of an underlying population.

Additional findings suggest that the prominence of mechanisms varies by party age. Grassroots linkage is more common among younger niche parties (the Pirate parties, as well as early Green parties (Kitschelt 1989)), which are likely to have more party members who are also active in movement contexts than their more institutionalized counterparts. Over the course of their development, niche parties can rely less on the organic occurrence of programmatic alignment with movements and need to invest in the other mechanisms, of which elite-level orientation 


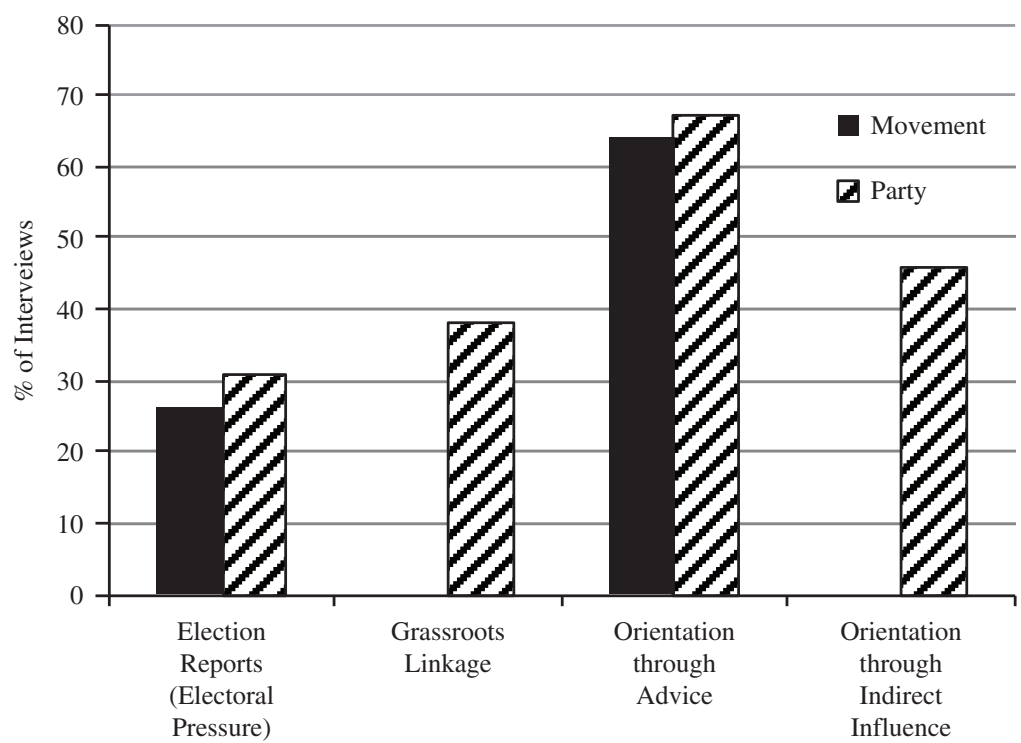

Figure 2. Mechanisms as Highlighted by $\%$ of Interviewees

is the most common; electoral pressure, while consistently present, remains inherently limited to the months before elections.

\section{Conclusion}

This article provided evidence for the three hypothesized mechanisms through which movement demands enter niche party platforms, creating programmatic alignment between parties and the movements that gave rise to them. In that way parties gain an ally that keeps their core issue salient, indirectly bolsters parties' issue ownership in voters', and in particular, in their core electorates' minds and works independently towards shared policy goals. Since all mechanisms allow SMOs to act in genuinely non-partisan ways, they do not damage the organizations' ability to influence other parties or to attract supporters from across the political spectrum. At the same time, movements profit from a party that pushes for their policies in the legislative arena and find themselves in a strong position vis-à-vis niche parties, because failing to establish the mechanisms can become a serious liability for parties. When the Swedish digital movement demobilized after 2009/10, for instance, the Pirates were left with few civil society actors that raised their issues independently, were willing to reinforce the party's issue ownership, or allowed for concerted policy campaigns. Party and movement elites saw the declining movement mobilization and the party's growing distance from it as one central reason for why the Pirates have struggled electorally since and lost their representation in the European Parliament in 2014 (interviews 020103, 020104, 020206).

The findings have implications for several areas of research. First, they further illuminate how the electoral incentives of niche parties diverge from those of 
mainstream parties. This article demonstrates that SMOs inform parties' core electorate about niche party positions. Recognizing these interactions between movements and niche parties refines our understanding of why these parties are constituency-focused (Ezrow et al. 2011). The results also imply that niche parties will be punished electorally when they shift their position away from their core issue and movements' policy positions. Exploring a related question, Gregor Zons (2016) finds that programmatic concentration benefits niche parties electorally at their origins but that this benefit decreases over time. This creates incentives for niche parties to broaden their issue profile, raising new questions. For instance, can a niche party broaden its policy appeals without creating conflict with the movements around it as long as the party retains core issue positions that reflect movements' demands? Many questions about conflicts between parties' vote- and policy-seeking goals, as well as between party and movement goals, remain to be explored.

Second, this article sheds additional light on movement strategies. The identified mechanisms constitute a successful approach by which movements engage with parties without trading their access for policy compromises, avoiding 'co-optation' (Gamson 1990). Thus, this article enhances our knowledge about the circumstances under which movements can achieve policy success, especially when a niche party is in government.

Third, this article points to SMOs as important actors in assigning issue ownership, again highlighting the problematic absence of civil society in the literature on political parties. Future research should further illuminate the role NGOs and movement mobilization play in changing citizens' perceptions of issue ownership. Considering that movements and NGOs enjoy much higher levels of trust in many countries than political parties, a reasonable initial hypothesis would be that their influence on issue ownership is stronger than that of parties.

Fourth, this article contributes to our understanding of contemporary shifts in patterns of participation. Even in times of decreasing party membership and engagement with political parties, niche parties remain strongly tied to civil society and citizens retain enormous influence through their increased level of issuefocused activism (Dalton 2008). This finding, moreover, has strong normative implications. By tying citizens to the state, niche parties and social movements provide a partial remedy for the increasing lack of political representation in advanced industrialized democracies. Both face incentives for programmatic alignment and, if successful, provide a channel for new demands to be represented in the political arena. Thus, they counterbalance a trend in mainstream parties, which in the process of professionalization have increasingly decoupled from civil society and focused on organizational self-interest (Katz and Mair 1995).

These findings also raise new questions. First, not all niche parties have movements around them with which to programmatically align. Are niche parties with movements around them more likely to thrive electorally? While this article has focused on parties in national contexts with partially institutionalized movements, it might not be necessary for movement activity to take these forms in order to keep issues salient and communicate a niche party's credibility to core constituencies. Some right-wing populist parties, for instance, are also surrounded by movement activities which often take less institutionalized and more violent forms. 
These contentious activities are by their nature newsworthy and keep the related issues on the agenda. Especially in the presence of digital echo chambers in which sympathizers can hear activists' messages, these movements might also be able to bolster the issue ownership of niche parties.

Second, how do different movement and party structures influence partymovement relationships? For instance, did the digital movement's reliance on electronic means of organization and mobilization contribute to the problems of establishing the alignment mechanisms in Sweden described above? Will movements gain increasing sway over mainstream parties, as these parties open up internal participation to non-members in an effort to engage voters more broadly (Scarrow 2015)?

Third, how are movement-niche party relationships impacted by different institutional contexts? As discussed above, Farrer (2014) has shown that institutional structures influence whether activists dedicate their effort to interest group or niche party strategies. Whether and how these structures change the behaviour of movement and party elites remains to be explored. What, for instance, are the implications of majoritarian electoral systems, in which pure niche strategies are less likely to lead to parliamentary representation, for the relationship between movements and niche parties?

Fourth, the influence of movements might differ depending on external events. Do events that place a niche party's core issue high on the agenda, such as the Fukushima nuclear disaster, lessen the influence of SMOs on the party, since the latter is less in need of allies to keep issues salient?

More broadly, this study demonstrates the need to illuminate the role of social movements in shaping parties and vice versa: what role do movements play in the recent breakthrough of movement-based parties like Podemos in Southern Europe? How does the evolution of movements from contentious mobilization to established NGOs influence the success they have in shaping parties and government policies? As these questions illustrate, much about party-movement interactions remains to be explored.

Supplementary material. To view the supplementary material for this article, please go to: https://doi. org/10.1017/gov.2018.18

Acknowledgements. I would like to thank Julia Azari, David Cunningham, Peter Enns, Sarah Maxey, Ken Roberts, Sid Tarrow, Chris Way, Thomas Zittel, the anonymous reviewers, as well as the participants of the Cornell Department of Government Research Colloquium and 2016 Young Scholars in Social Movements conference at the University of Notre Dame for their extremely helpful suggestions and comments. Research affiliations with the Institute of Future Studies in Stockholm and the Goethe University in Frankfurt made this project possible. I gratefully acknowledge the support of this research by a Luigi Einaudi Fellowship from the Cornell Institute for European Studies and a research travel grant from Cornell's Graduate School.

\section{Notes}

1 Existing work, like Katz and Mair's (1995) seminal contribution, considers parties' drift from their civil society roots more generally, as well as party-interest group relationships (e.g. Rasmussen and Lindeboom 2013) and Green parties' connections to movements (e.g. Frankland et al. 2008), but systematic attention to the movement roots of niche parties as a party type is lacking.

2 See e.g. Burchell (2002) on the professionalization of Green parties. 
3 I follow McAdam et al. (2001: 24) in defining mechanisms as 'a delimited class of events that alter relations among specified sets of elements in identical or closely similar ways over a variety of situations'. 4 Studies have demonstrated this empirically and for example shown that interest group-party relations are only weakly institutionalized (Rasmussen and Lindeboom 2013). Moreover, mainstream political parties have de-emphasized their original issue focuses while growing to major party status. See Przeworski and Sprague (1986).

5 Several authors have proposed modified definitions. Wagner (2012: 845) suggests conceptualizing niche parties as focusing on a 'small number of non-economic issues'. Meyer and Miller (2015) advocate taking mainstream parties' relative positions into account. Bischof (2017: 223) identifies a niche strategy as '(a) predominantly competing on niche market segments neglected by their competitors; (b) not discussing a broad range of these segments.' The parties discussed in this article conform to all of these definitions. 6 I use the term 'digital movement' for organizations and activists focusing on copyright reform, the protection of privacy, and generally information-related issues. This movement makes extensive use of electronic means of communication. Thus, the term reflects the content and the most prominent form of activism.

7 The two Green parties and the German Pirates are leftist parties, while the Swedish Pirates' position on that dimension is more centrist. In the 2014 Chapel Hill expert survey the Swedish Pirates were classified as centrist, receiving an average value of 5 on the left/right dimension ranging from 0 to 10 (Polk et al. 2017). 8 See the online appendix for the full questionnaire.

9 In less institutionalized movement environments, like the Swedish digital movement, I also contacted prominent activists directly.

10 Participants were assured that they would remain anonymous but agreed that their interviews could be attributed through a description of their role within the party or as representatives of their SMO.

11 This also ensured that the SMOs included in this study did not systematically differ in their interactions with parties from SMOs with which interviews could not be realized.

12 Percentages of interviews are given to provide a sense of how many interviewees thought of a particular activity as important enough to highlight it, not as observations representative of an underlying population.

13 Ten of the 12 interviewees who referenced this mechanism and indicated the level at which it works.

14 Eleven of 15 references to this mechanism were made by Pirate Party leaders.

15 About $64 \%$ of party and $68 \%$ of movement interviewees discussed this mechanism.

16 Brokerage is 'the linking of two or more previously unconnected social sites by a unit that mediates their relations with one another and/or with yet other sites' (McAdam et al. 2001: 26).

\section{References}

Adams J, Clark M, Ezrow L and Glasgow G (2006) Are Niche Parties Fundamentally Different from Mainstream Parties? The Causes and the Electoral Consequences of Western European Parties' Policy Shifts, 1976-1998. American Journal of Political Science 50, 513-529.

Adams J, Ezrow L and Leiter D (2012) Partisan Sorting and Niche Parties in Europe. West European Politics 35, 1272-1294.

Bale T and Bergman T (2006) A Taste of Honey is Worse than None at All? Coping with the Generic Challenges of Support Party Status in Sweden and New Zealand. Party Politics 12, 189-209.

Bischof D (2017) Towards a Renewal of the Niche Party Concept: Parties, Market Shares and Condensed Offers. Party Politics 23, 220-235.

Bischof D and Wagner M (2017) What Makes Parties Adapt to Voter Preferences? The Role of Party Organisation, Goals and Ideology. British Journal of Political Science, published early online, December. https://doi.org/10.1017/S0007123417000357.

Blühdorn I (2009) Reinventing Green Politics: On the Strategic Repositioning of the German Green Party. German Politics 18, 36-54.

Bolleyer N, Little C and von Nostitz F-C (2015) Implementing Democratic Equality in Political Parties: Organisational Consequences in the Swedish and the German Pirate Parties. Scandinavian Political Studies 38, 158-178.

Boström M (2008) The Historical and Contemporary Roles of Nature Protection Organizations in Sweden. In Van Koppen K and Markham WT (eds), Protecting Nature. Organizations and Networks in Europe and the USA. Cheltenham: Edward Elgar Publishing), pp. 213-238. 
Burchell J (2002) The Evolution of Green Politics: Development and Change within European Green Parties. London: Earthscan.

Dalton RJ (2008) Citizen Politics: Public Opinion and Political Parties in Advanced Industrial Democracies, 5th edn. Washington, DC: CQ Press.

Demker M (2014) Sailing Along New Cleavages: Understanding the Electoral Success of the Swedish Pirate Party in the European Parliament Election 2009. Government and Opposition: An International Journal of Comparative Politics 49, 188-206.

Dobusch L and Gollatz K (2012) Piraten Zwischen Transnationaler Bewegung und Lokalem Phänomen. In Bieber C and Leggewie C (eds), Unter Piraten. Erkundungen in Einer Neuen Politischen Arena. Bielefeld: transcript, pp. 25-40.

Ezrow L, De Vries C, Steenbergen M and Edwards E (2011) Mean Voter Representation and Partisan Constituency Representation: Do Parties Respond to the Mean Voter Position or to Their Supporters? Party Politics 17, 275-301.

Farrer B (2014) A Theory of Organizational Choice: Interest Groups and Parties as Substitutable Influence Mechanisms. Party Politics 20, 642-645.

Frankland EG, Lucardie P and Rihoux B (eds) (2008) Green Parties in Transition: The End of Grass-Roots Democracy? Farnham: Ashgate.

Gamson W (1990) The Strategy of Social Protest, 2nd edn. Belmont: Wadsworth.

Häusermann S and Kriesi H (2015) What Do Voters Want? Dimensions and Configurations in Individual-Level Preferences and Party Choice. In Beramendi P, Häusermann S, Kitschelt $\mathrm{H}$ and Kriesi H (eds), The Politics of Advanced Capitalism. New York: Cambridge University Press, pp. 202-230.

Hernández E and Kriesi H (2016) The Electoral Consequences of the Financial and Economic Crisis in Europe. European Journal of Political Research 55, 203-224.

Johnston H (2011) States and Social Movements. Malden, MA: Polity.

Junker S (ed.) (2014) Rapport: Miljölöften För Europa Miljögranskning Av Svenska Toppkandidater Inför EU-Valet 2014. Stockholm: Naturskyddsföreningen.

Katz RS and Mair P (1995) Changing Models of Party Organization and Party Democracy: The Emergence of the Cartel Party. Party Politics 1, 5-28.

Kirchheimer O (1966) The Transformation of Western European Party Systems. In LaPalombara J and Weiner M (eds), Political Parties and Political Development. Princeton: Princeton University Press, pp. 177-200.

Kitschelt H (1988) Left-Libertarian Parties: Explaining Innovation in Competitive Party Systems. World Politics 40, 194-234.

Kitschelt H (1989) The Logics of Party Formation: Ecological Politics in Belgium and West Germany. Ithaca: Cornell University Press.

Kitschelt H (2000) Linkages between Citizens and Politicians in Democratic Polities. Comparative Political Studies 33, 845-879.

Kitschelt H (2006) Movement Parties. In Katz RS and Crotty W (eds), Handbook of Party Politics. London: Sage, pp. 278-290.

Kriesi H, Koopmans R, Duyvendak JW and Giugni MG (1995) New Social Movements in Western Europe. Minneapolis: University of Minnesota Press.

Lawson K (ed.) (1980) Political Parties and Linkage: A Comparative Perspective. New Haven: Yale University Press.

Lawson K (2004) Five Variations on a Theme: Interest Aggregation by Party Today. In Lawson K and Poguntke T (eds), How Political Parties Respond: Interest Aggregation Revisited. London: Routledge, pp. 250-266.

Lindgren S (2013) Pirate Panics: Comparing News and Blog Discourse on Illegal File Sharing in Sweden. Information, Communication \& Society 16, 1242-1265.

Lipset SM and Rokkan S (eds) (1967) Party Systems and Voter Alignments: Cross-National Perspectives. New York: Free Press.

Little C (2016) Green Parties in Government. In van Haute E (ed.), Green Parties in Europe. New York: Routledge, pp. 265-279.

Marx P and Schumacher G (2013) Will to Power? Intra-Party Conflict in Social Democratic Parties and the Choice for Neoliberal Policies in Germany, the Netherlands and Spain (1980-2010). European Political Science Review 5, 151-173. 
McAdam D and Tarrow S (2010) Ballots and Barricades: On the Reciprocal Relationship between Elections and Social Movements. Perspectives on Politics 8, 529-542.

McAdam D, Tarrow S and Tilly C (2001) Dynamics of Contention. Cambridge: Cambridge University Press.

Meguid BM (2005) Competition between Unequals: The Role of Mainstream Party Strategy in Niche Party Success. American Political Science Review 99, 347-359.

Meguid BM (2008) Party Competition between Unequals: Strategies and Electoral Fortunes in Western Europe. Cambridge: Cambridge University Press.

Meyer TM and Miller B (2015) The Niche Party Concept and Its Measurement. Party Politics 21, $259-271$.

Meyer TM and Wagner M (2013) Mainstream or Niche? Vote-Seeking Incentives and the Programmatic Strategies of Political Parties. Comparative Political Studies 46, 1246-1272.

Müller WC and Strøm K (eds) (1999) Policy, Office, or Votes? How Political Parties in Western Europe Make Hard Choices. Cambridge: Cambridge University Press.

Naturskyddsföreningen (2014) Snabbguide - Så Vill Partierna Jobba För Miljön. www.naturskyddsforeningen.se/partiernasmiljopolitik.

Panebianco A (1988) Political Parties: Organization and Power. Cambridge: Cambridge University Press.

Pardos-Prado S (2015) How Can Mainstream Parties Prevent Niche Party Success? Center-Right Parties and the Immigration Issue. Journal of Politics 77, 352-366.

Petrocik JR (1996) Issue Ownership in Presidential Elections with a 1980 Case Study. American Journal of Political Science 40, 825-850.

Polk J, Bakker R, Edwards E, Hooghe L, Jolly S, Koedam J, Kostelka F, Marks G, Schumacher G, Steenbergen M, Vachudova M and Zilovic M (2017) Explaining the Salience of Anti-Elitism and Reducing Political Corruption for Political Parties in Europe with the 2014 Chapel Hill Expert Survey. Research and Politics 4, 1-9.

Przeworski A and Sprague J (1986) Paper Stones: A History of Electoral Socialism. Chicago: University of Chicago Press.

Rasmussen A and Lindeboom G-J (2013) Interest Group-Party Linkage in the Twenty-First Century: Evidence from Denmark, the Netherlands and the United Kingdom. European Journal of Political Research 52, 264-289.

Rucht D and Roose J (2004) Germany. In Rootes C. (ed.), Environmental Protest in Western Europe. Oxford: Oxford University Press, pp. 80-106.

Scarrow SE (2015) Beyond Party Members: Changing Approaches to Partisan Mobilization. Oxford: Oxford University Press.

Tarrow S (1998) Power in Movement: Social Movements and Contentious Politics, 2nd edn. Cambridge: Cambridge University Press.

Wagner M (2012) Defining and Measuring Niche Parties. Party Politics 18, 845-864.

Walgrave S, Lefevere J and Tresch A (2012) The Associative Dimension of Issue Ownership. Public Opinion Quarterly 76, 771-782.

Zons G (2016) How Programmatic Profiles of Niche Parties Affect Their Electoral Performance. West European Politics 39, 1205-1229.

Cite this article: Blings S. (2020). Niche Parties and Social Movements: Mechanisms of Programmatic Alignment and Party Success. Government and Opposition: An International Journal of Comparative Politics 55: 220-240, https://doi.org/10.1017/gov.2018.18 